\title{
Law of attraction: A mirror image of Zimbabwe-Belarus relations
}

\section{Lucid Chirozva}

International Relations, Africa University, Mutare, Zimbabwe

chirozvalt@gmail.com

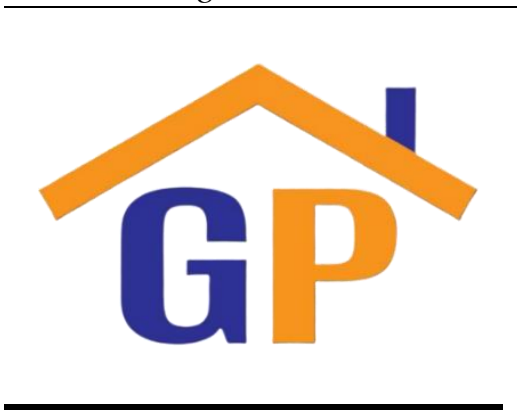

Article History

Received on 27 July 2021

Revised on 9 August 2021

Accepted on 9 August 2021

\begin{abstract}
Purpose: The study aims to analyse the law of attraction and its influence on Zimbabwe-Belarus relations.
\end{abstract}

Research methodology: Secondary sources that relate to Zimbabwe and Belarus were used to gather data. The content analysis technique was employed to analysis to the data.

Results: The study gathered that the two countries have limited allies in the international system; they are all on sanctions from the European Union (E.U.) and the United States of America (U.S.A.). The two countries also behave the same way in their interactions domestically and politically, as demonstrated by their conduct during elections.

Limitations: The study focuses explicitly only on Zimbabwe's 2018 and Belarus's 2020 elections

Contribution: This study contributes to understanding how the law of attraction will play a new role in determining the relations shortly, specifically whether or not the two counties will remain allies.

Keywords: Belarus, Law of attraction, Relations, Zimbabwe

How to cite: Chirozva, L. (2021). Law of attraction: A mirror image of Zimbabwe-Belarus relations. Dynamics of Politics and Democracy, 1(1), 39-48.

\section{Introduction}

This study seeks to unpack the universal law of the law of attraction and its influence on BelarusZimbabwe relations. This study provides the significance of this research to the International relations discipline, policy-making, and implementation amongst international political agencies. The constructivism theory is the major international relations theory that was used as a tool of analysis. The paper also examines the concept of the law of attraction in the context of Belarus Zimbabwe Relations. This relevant piece of literature unpacks the relationship between Belarus and Zimbabwe and also the influence of the law of attraction on the Belarus-Zimbabwe foreign interactions. The secondary source was like books, newspapers, magazines, internet sources were used to gather data. The research also used observation as a tool for gathering data. Zimbabwe and Belarus have similar political behaviours that have worsened their reputation within the international system. It is, for this reason, the two counties find themselves in the same corner and forced the two to find each other for political comfort. The law of attraction is a powerful universal law that could be used to measure state interactions in international political debates.

\section{Literature review}

This research aims to examine the relations between Zimbabwe and Belarus, to ascertain the extent to which the law of attraction is a factor in determining Zimbabwe- Belarus relations. There is limited literature on Zimbabwe-Belarus relations despite an increase in cooperation between the two countries since 2015. Although there has been a considerable academic debate on what influences state relations in the international system, there has been an absence of in-depth research and analysis on the law of attraction as a powerful universal law that attracts States to interact. This study shall demonstrate systematically and logically that the law of attraction determents the relations amongst states in the 
international system. This will add impetus to the existing body of literature on foreign policy and international relations.

The pieces of literature available focus on Belarus politics and other contemporary issues without analysing Belarus relations with any African country. Van Der Togt T (2017) researched Belarus, Russia, and E.U. integration. Lahviniea A and Papko A (2010) analysed the unfinished business and challenges of Belarus on its way to Democracy. Tranticlis A (2021) examined strategies for authoritarianism and resistance in Belarus and Slovakia. The literature gap between the above publications and this study is that this research aims to reflect on the relationship between an African country and a European country. There is a lot of debate amongst International Relations scholars on whether Euro-Africa inter-state relations have imperialist tendencies. However, in the context of the law of attraction, states with the same political behaviours are bedfellows.

Writings available on Zimbabwe are silent on the interestingly emerging Zimbabwe-Belarus foreign affairs discourses. Melber H and Southfall R (2021) examine Zimbabwe's foreign policy under Mnangagwa. Masunungure E and Badza S (2010), scrutinised the internationalisation of the Zimbabwe crisis, focusing on the multiple actors and competing interests. Hove M, Ndawana E, and Nhemachena M A (2020) assessed how Cuba survived sanctions and the lessons for Zimbabwe. The pieces of writings above did justice to their objectives however this study is unique in the sense that it is focusing on one of the emerging contemporary and foreign relations of an Africa state in the post colony. The two political entities possess similar configurations of political ideologies. The question which one should seek to address is, could these similarities and the cordial relations between the two be a result of the natural law of attraction?

This research is significant because it brings to light a newly emerging theme in the international relations discourse. The new emerging discourse of the law of attraction as a determinant to the interactions of the actors of international relations will be relevant as a tool of analysis to determine factors that influence foreign policies. Policymakers, policy implementers, and academic intellectuals shall benefit from this piece of work. The relevance of this piece of literature rests in the development of compressive bi-lateral agreements, and other international legal instruments as countries are pursuing their national goals and agendas. Jurists and diplomats need to know what influenced their countries' foreign policy when negotiation in international agreements.

The Constructivist theory is found to be appropriate for this study as a theoretical tool of study. Onuf. Johari J C (2009) was right when he noted that all relations whether international or national, subregional or regional consist of thoughts and ideas and not essentially of material conditions of force. Griffiths M and Callaghan T. O (2002) note that social constructivism offers a form of international affairs that explores the normative manipulation of elementary institutional composition and the link between and state identity, interests and normative changes". States have a corporate identity that generates basic state goals, such as physical security, stability, recognition by others, and economic development. State interactions in the field of international relations are shaped by identities over time and not among predetermined national interests. The advantage of using constructivism as a tool of analysis, as noted by Theys S (2018) is that the discipline of International Relations benefits from constructivism as it addresses issues and concepts that are neglected by mainstream theories especially realism. Doing so, constructivists offer alternative explanations and insights for events occurring in the social world This research is of the view that what is known, seen, and thought about the world is socially constructed and States with similar social norms are likely to have friendly relations in a process where states behaviours in a certain way which they correct, it called the logic of appropriateness. These demonstrate while Zimbabwe and Belarus are allies in the international relations of their social norms that are similar as demonstrated by this research

\section{Research methodology}

The data was gathered through secondary sources and observation as a primary method of collecting data. Blackstone K (2020) urges that a secondary source is a document or recording that transmits or converses information originally presented elsewhere. Secondary sources were very useful in giving 
the researcher a grasp of the subject and the provision of extensive bibliographic information for delving further into the research topic. Secondary data was gathered from various scholarly journals and books, newspapers and magazines, archival material, declassified operational reports, unpublished theses, and the internet, as well as seminar papers. The benefits of using secondary sources are that they are easy to access, low cost to attain; elucidation of the research question may answer research subject and may confirm impenetrability in carrying out primary. https://www.historylearningsite.co.uk/sociology/research-methods-in-sociology/secondary-sources/

\section{Data analysis}

To analyse the data acquired, the study employed content analysis. Content analysis is a research utensil employed to find out the presence of certain words or concepts within texts or sets of texts. The study analysed the existence, meanings, and relationships of words and concepts, and then made inferences about the messages within the texts in the literature available in the secondary sources used to gather data. Bryman A (2011) noted that Content analysis is the study of documents and communication artifacts, which might be texts of various formats, pictures, audio, or video. Social scientists use content analysis to examine patterns in communication in a replicable and systematic manner. https://www.historylearningsite.co.uk/sociology/research-methods-in-sociology/secondary-sources/.

\section{The concept of law of attraction in the context of Belarus-Zimbabwe relations}

The Law of Attraction is among the most popular of the Universal Laws. Whittaker S (2017) echoed that the Law of Attraction is the belief that positive or negative thoughts bring positive or negative experiences into a person's life. Whittaker S (20170 believes that the belief is based on the idea that people and their thoughts are both made from pure energy and that through the process of negative energy attracting negative energy a person can improve their health, wealth, and personal relationships. This study assumes that the law of attraction is the most fundamental of all universal laws, as demonstrated by Zimbabwe-Belarus relations. The two countries have similar political behaviours that have shaped their international relations, thus resulted in the two countries being closer allies as they seek to survive in the international political system. The law of attraction has influenced countries with similar behaviour and similar interests that are not conflicting with having cordial relations. The law of attraction manifests through thoughts, by portraying thought and ideas of a similar kind, states' governance styles, and also corresponding situations and circumstances. To this end the global system is anarchical; therefore, allying with countries with the same political system, governance style, internal and external threats, and international relations will only strengthen the chances of a country's survival in the global arena. A country's (Zimbabwe) foreign policy formulation and implementation, diplomatic methods, and strategies charm relations with a country (Belarus) with similar foreign and domestic policy styles and ward off countries with tangent foreign policy and domestic policy. This is what Zimbabwe and Belarus desire and expert that brings to each country the conditions and experience that the two states predominantly practice.

The law of attraction clearly shows that States with similar allies and enemies are likely to have friendly relations. A states' behaviour attracts states with the same behaviour as hers. This study assumes that in international politics tyranny attracts tyranny, despotism attracts despotism, revolutionary attracts revolutionary. Zimbabwe and Belarus relations are countries with the expectations coming together as a surviving strategy in the international system. Haanel C pronounced (1912) that "the law will certainly and unerringly bring to you the conditions, environment, and experiences in life corresponding with your habitual, characteristic predominant mental attitude". The above relates with what Raph Trine wrote in In Tune with the infinite (1897) that "The law of attraction works universally and states attract what they desire and international actors attract what they wish for. The way Zimbabwean and Belarus are similar in how they hold their election and how brutal they have been to their citizens, one may think that the two friendly counties always exchange notes on how to exercise authoritarianism. This is indicated by the conduct of Zimbabwe in pre, during, and post-elections in all elections held in Zimbabwe since 1980 and all elections held in Belarus since 1994. The similarity in which the governments of the two countries conducted themselves is a manifestation that no other countries in the global system do not know what to be associated with the two countries. It should be noted that the limitation of allies has force Belarus and Zimbabwe to find one other, thus expressing the power of the 
law of attraction in international relations. It should be noted that 21 century is an era where nonalignment in an age of alignment is naivety and naivety is dangerous in international politics.

The available literature on the law of attraction focuses mainly on its influence on individual or personal relations. This paper is more concerned with analysing its impact on State relations. The relations between Zimbabwe and Belarus since 2015 have raised questions amongst intellectuals since the two counties have sour relations with the U.S.A. and its allies, they have arguably poor human rights records, and they are both nursing the wounds of sanctions from the E.U. and the U.S.A. This study examines if the factors mentioned above are the rationale behind the emergence of the recent cordial relations between the two counties. William Walker Atkinson in his new thought movement book (1906) he stated that "like attracts like" and in 1910 he published the science of getting rich in which he claimed the negative thinking will manifest negative results. Applying this in international relations implies that good or bad state morality will determine the country's outcome of its worldly experiences.

It should be noted that it is what Zimbabwe desires which led to its cordial relations with Belarus. The two countries are attracted to each other because of similarities to their foreign affairs, domestic policies, and national interests. They have seen it necessary to be allies because of the primary goal to survive in the uncertain, unpredictable international system. They appeal to each other because they share almost similar historical experiences, from independence, bad international publicity, and sanctions.

In the international system, relations are not always driven by national interests. There are some aspects of international relations which are historically and socially constructed. The last quarter of the $20^{\text {th }}$ century and the early 21 st century has witnessed the restructuring of the international relations discourse. The Post-cold war has witnessed ideas/ ideologies determining relations between political entities in world affairs. Thoughts can define, redefine and restructure the behaviour of a state and in that way transmogrify the body of international relations and politics. These socially constructed ideas can shape and reshape the interests and identity of the state.

\section{Findings and discussions}

\section{Unpacking the Zimbabwe-Belarus relations}

The countries have engaged in bilateral activities since Belarus gained independence in 1994, but the significant engagements started with the visit to Belarus made by H.E J.Nkomo as Vice President of Zimbabwe in 2011. 2011 marked the intensification of bilateral indenture because delegations of both countries have repeatedly visited Minsk and Harare. In January 2019, the primary executive visit to Belarus by President Mnangagwa of the Republic of Zimbabwe took place. He meets H.E. Alexander Lukashenko, President of the Republic of Belarus, and the signing of several international treaties.http://rsa.mfa.gov.by/docs/belarus_zimbabwe_en.pdf.

Kuda Bwitit (2015) reported that in 2015 Vice President Emmerson Dambudzo Mnangagwa met Belarus President Alexander Lukashenko and went on to sign the M.O.U. with Prime Minister Andrei Kobyakov at the Palace of Independence in Minsk. Sasa M (2019) The memorandum signed between the V.P. of Zimbabwe Mnangagwa and Prime Minister Kobyakov intended to see Belarus firms supply of paraphernalia worth \$US150 million to Zimbabwe industrial and infrastructural development. The financing of this initiative was to be coordinated by the States' Central Banks (Development Bank of Belarus and the Reserve Bank of Zimbabwe). This marked the milestone in strengthening the cooperation between the two countries that are seemingly attracted to each other because they share the same social and political norms.

The Herald (2017) reported that the president of Belarus expressed his excitement about the visit by Zimbabwe's delegation, and he expressed his willingness to make sure that Harare and Minsk are united in their quest to burst the western sanctions imposed on them. Vice President of Zimbabwe Emmerson Mnangagwa echoed the same sentiments by saying that "the Belarus president was fully aware of the plethora of challenges Zimbabwe was facing, mostly from the Americans and European Union (E.U.). The need to burst the western sanctions imposed on the two countries is the fundamental energy pulling the magnetic poles of the two counties closer, thus expressing the explanatory vigour that the law of attraction has in international relations. 
President Mnangagwa succeeded President Mugabe in Zimbabwe in 2017 and embarked on a fournation tour to Eurasia. This was Zimbabwe's economic diplomacy thrust whose intention is to stimulate Zimbabwe's road to a middle-income economy by 2030. Sasa M (2019) reported that the President of Zimbabwe was invited by the leaders of Russia, Belarus, Azerbaijan, and Kazakhstan to strengthen existing economic and political relations with the first two and forge new mutually beneficial partnerships. The Herald (2019) reported that during President Mnangagwa to Belarus, the two countries sealed eight agreements, also agreed to work together to make Zimbabwe a regional transport and logistics hub. They agreed to link the Atlantic and the Indian oceans by constructing a road and rail network across Southern Africa and through Zimbabwe. The construction of this road and rail network would be under a Zimbabwe-Belarus-China tripartite arrangement. The tripartite agreement positioned Zimbabwe as foci in this infrastructure development in Southern Africa, indicates the level of trust and appetite for cooperation between the countries involved. Two countries suffocated by western sanctions found each other and tried to aid each other through bilateral relations. The law of attraction in this scenario is justified as a powerful universal law in international politics because Zimbabwe and Belarus are two countries comparably too ignorant of democratic values, trying to help each because they find themselves in a similar predicament of limited friends, because of their unimpressive record of corruption and political crisis and mismanagement of public funds.

The Herald (2019) reported that the two countries also agreed that Belarus should invest in irrigation systems, residential housing, roads, and a 100MW solar power plant mining in prime gold, chrome, and lithium. The Herald (2019) detailed that to facilitated commerce and logistics from a land-locked country Zimbabwe to the ports, a Belarusian transport company with an initial 1000 trucks will be registered. Zimbabwe and Belarus concluded major agreements on joint production and processing of beef, poultry, pork, dairy, horticulture, fruits, wheat, and maise. The Herald (2019) quoted President Mnangagwa echoing that "this is how friendly countries should interact." President Lukashenko said that Zimbabwe is Belarus' strategic partner in Africa. Sasa M (2019) noted that, In Belarus, President Mnangagwa laid a wreath in respect of an estimated 2; 6 million Belarusians killed in World War II at the Victory Square monument and also visited the Christian Orthodox Church Memorial Cathedral and lit a symbolic candle there. Belarus is Zimbabwe's strategic partner in Eastern Europe like Zimbabwe is to Belarus in Southern Africa.

The two internationally countries dream of opening new markets to strengthen their economic capabilities in the international system. Sasa M (2019) maintains that Zimbabwe and Belarus are on the brink of concluding major agreements on joint production and processing of beef, poultry, pork, dairy, horticulture, fruits, wheat, and maise. This is how it should be between friendly countries. Sasa M (2019) conveyed what President Mnangagwa said of the agreements, that Zimbabwe would benefit immensely from Belarus's experience. Belarus has gone through similar challenges as Zimbabwe is presently going through. President Lukashenko responded by saying, Belarus and Zimbabwe are loyal and sincere friends, adding that Belarus considered Zimbabwe a strategic partner in Africa.

The Herald Zimbabwe (2019) reported that on 17 September 2019, Zimbabwe and Belarus signed deals worth \$US350 as they strengthen the relationship through transactional diplomacy in Harare. Two countries were represented by top officials. Dr. Sibusiso Moyo was the Minister of Foreign Affairs and International Trade representing Zimbabwe, while General Colonel Victor Sheiman, the Chief of President Affairs, represented Belarus. The two also preside on the signing of a Memorandum of Understanding (M.O.U.) that launched the Joint Permanent Commission on Cooperation (JPCC), which was followed by the MoU on the collaboration, association, and support of the joint Harare Minsk construction. The two countries also agreed to work together in the construction of a power plant, transport, logistics, and development of agricultural projects. Belarus mandated to bring technology, finance, and equipment to build lower and medium houses in Zimbabwe's cities to enhance housing development in Zimbabwe.

It should be pointed out that following the President of Zimbabwe, President Mnangagwa's visit to Belarus, the cooperation between the two countries reached new heights. Belarus offered Zimbabwe 500 buses. This initiative was aimed to improve Zimbabwe's public transport and a 
first step in turning Zimbabwe into a regional transport hub. Zimbabwe's Minister of Information, Publicity and Broadcasting Services reported that 500 buses were offered and there is a prospect of increasing the number in the future. The Herald Zimbabwe (2019) noted that subsequently after the trip by the President of Zimbabwe to Belarus Lukashenko signed contracts for $\$ 58$ million for the supply of tractors and equipment for forestry and about a $\$ 10$ million contract for the supply of Belarusian fertilisers to Zimbabwe. In an interview with the T.V. channel "Belarus 1" (2019), Sheiman spoke about Belarus's readiness to cooperate with Zimbabwe in various fields. In particular, it was decided to establish a joint venture for the processing of meat and milk. Belarus also plans to rehabilitate the irrigation system and build dams, roads, and housing in Zimbabwe. Belarus is interested in exploring and producing oil, gas, gold, platinum, and other resources in Zimbabwe. There are mutual relations between the two countries determined by the need to cooperate in areas of the critical need for the development and survival of two allies who are attracted to each other because they are perceived as the axis of evils by the western world U.S.A.

It is interesting to note that the two countries are the twin evils of the international political system. The announced plans and megaprojects are partly official fantasies and projections. Zimbabwe is a deeply corrupt country with extremely high levels of debt. It is interesting to notice that bilateral relations with one of the poorest African countries are supervised by Sheiman, who has always been involved in Lukashenko's embellishment of sensitive transactions with an elevated level of confidentiality. The two twin evils of the international system are attracted to each other because they conduct themselves the same way despite differences in their geographical locations

Sheiman (2018) pointed out, cooperation in several sectors can boost Belarusian-Zimbabwean economic relations. He stresses extracting mineral resources, constructing industrial and resident buildings, delivering Belarusian tractors and Lorries, and exporting Belarusian fertilisers. The two sides discuss the possibility of organising the assembly and production of Belarusian agricultural and mining vehicles in Zimbabwe and establishing joint agricultural enterprises like meat- and milk-processing ones. As of mid-2018, five companies with Belarusian capital operating in Zimbabwe. The most eyecatching of all has been the cooperation in diamond extraction. Sheiman (2018) quoted Mnangagwa saying, thanks to vehicles from Belarus, diamond extraction had doubled in the African state. Thus, given Zimbabwe's needs to develop its agriculture and infrastructure and rich mineral reserves, the Belarusian authorities hope that engagement with that country can become strategic and will, in turn, open up new opportunities for Belarus in Africa. The bond between the two countries is strong and galvanised by the objectives of each country to survive the slaughter from other competing international actors of the brutal international system. Zimbabwe-Belarus relations are motivated by the congruence in the countries' foreign and domestic policies.

\section{Law of attraction as determinant to Zimbabwe-Belarus relations}

Belarus and Zimbabwe's relations with the rest of the world have been extremely poor. The two countries are attracted to each other because they find themselves in the same political corner. They are both under sanctions from powerful international relations actors like the European Union and the U.S.A. On 31 January 2011, the Foreign Affairs Council of the European Union agreed to impose sanctions on individuals in Belarus by issuing travel bans and freezing assets of those involved in the 2010 flawed presidential elections and the post-election crackdown on Belarusians disgruntled citizens. E.U. further increased sanctions in 2012 by increasing numbers of the Belarus politician on the targeted list, freezing assets of companies linked to the regime, and an arms embargo and export ban on materials that could be used for brutal internal repression https://www.globalsecurity.org/military/world/belarus/forrel.htm. Zimbabwe is also under sanction, just like Belarus. The EU-Zimbabwe relations got strained due to allegations of human rights abuses and disrespect of the rule of law in Zimbabwe. The E.U. rejected the verdict of 2002, 2005, 2008 rerun, and 2013 election in Zimbabwe, which the E.U. did not observe. The central E.U. legislation concerning Zimbabwe is Council Regulation (E.C.) No 310/2002 that entered into force on 18 February 2002. This legislation endows an arms embargo and proscribes on the export of paraphernalia for internal subjugation in Zimbabwe, amongst other sanctions in Zimbabwe. In February 2004, the embargo was renewed by the Common Position 2004/161/CFSP and Council Regulation (E.C.) No 
314/2004 of February 2004 renewed and modified the E.U. arms embargo on Zimbabwe. This E.U. instruction initiated prevention on the granting, selling, supply, or transfer of technical aid associated with military utensils to Zimbabwe https://www.globalsecurity.org/military/world/africa/zwforrel.htm. In international politics, the enemy of your enemy is necessary strategically. The international political position of Belarus and Zimbabwe is a situation of two political entities with limited allies in the international system because of their alleged tyrannical forms of government. The tyranny philosophical ideology has a magnetic effect on the attraction between the counties and this justifies the law of attraction as the determinant factor in Zimbabwe-Belarus relations.

Belarus and Zimbabwean government's model of operation are, no regime remains in power based on political legitimacy or administrative efficiency. The regime's survival is underpinned by the exercise of cohesive power of the military, the police. The use of police and military in politics is in the D.N.A. of Belarus and Zimbabwe, as reflected by the involvement of the police prior, during, and post-every election in both countries. Heywood A (2007) argues that policing can be political in many ways. It can be carried out in harmony with certain party-political biases or social bigotries that favour certain groups or interests over others. Policing and militarism may encompass outside civil matters and impact specifically political disputes. Heywood A (2007) noted that working-class, civil societies, racial, ethnic minorities, opposition parties are likes to be assemblages treated less compassionately by the police and the military. Zimbabwe and Belarus are two examples of international relations entities where the discipline and training of the police force and the nature of police work itself tend to breed a culture that is politically conservative and socially authoritarian. The similarities of the two states regarding the role of police and military in their politics extend to the attractiveness to each other, as indicated by the suppression of protests in the post-2020 Belarus and 2018 Zimbabwe elections. The aftermath of the 2018 Zimbabwe and 2020 Belarus elections were marred with protests that were countered by state brutality to its civilians. The protestors were caused by issues of voter irregularities, election fraud, and election results announcement delays. In Zimbabwe K Mahr, (2018) wrote that the army opened fire on demonstrators, bystanders and killing six people in Harare. The following days witnessed an increase in the number of arrests of the opposition party members. In Belarus, just like in Zimbabwe, there was a clash between the protestors and the police in Munsk, B.B.C. News (19 August 2020) reported that injuries and the use of stun grenades and rubber bullets emerged and protesters barricaded the area around the Riga market. Security forces responded by tear-gassing the protesters and using flashbangs. These were responses of two militant regimes that are not willing to surrender power. The extent to which these two allies are eager to go for regime survival can lead one to conclude that the two allied states exchange notes on how to deliver these diabolical acts of despotic proportions.

The two countries are perceived by their nemesis (states and non-state actors) as countries ignorant of the rule of law despite both countries begin signatories to international human rights instruments like the United Nations Declaration on Human Rights of 1948. Elections in Belarus have been deemed unfair since 1994. In Zimbabwe, the election process is always reported to be not reflecting the will of the people since 1980. Organisation for Security and Co-operation in Europe (OSCE) report on the October 2004 parliamentary elections in Belarus that, December 2004 elections were not free because of the opposition's poor results and media bias in favour of the government. Although it is not justifiable for the OSCE to base the unfairness of the election results on poor opposition results, the media biased towards the ruling party can be singled out as a reflection of an election held under an uneven ground or environment. The elections in Zimbabwe were held under fraud rent matter since independence, 2002, 2005, 2008, 2013, 2018 elections in Zimbabwe were all deemed unfair by some states and nonstates observers and not reflecting the will of the people

The 2018 elections in Zimbabwe and 2020 Belarus elections presented similarities and justified the relevance of the law of attraction in the international system. In Belarus, President Lukashenka has won every election since 1994 and was re-elected in 2020 by $80 \%$. All the elections held in Belarus since 1994 have been labelled as not free and fair by international monitors. In 2020 the opposition in Belarus under Sviatlana Tsikhanouskaya, just like in 2018, the opposition under Nelson Chamisa, claimed to have won the election. Both the opposition in the respective countries appealed to the relevant court in their countries. The opposition in Belarus filed their appeal to the Central Election Commission, and 
the Zimbabwean opposition filed their appeal to the Constitutional Court of Zimbabwe. Farai M (2018) reported that on 24 August 2018, the Supreme Court of Zimbabwe dismissed Chamisa's challenge and officially declared Mnangagwa, the winner in a unanimous ruling. In Belarus, Sky News (19 August 2020) reported that On 19 August, the Belarusian Central Election Committee said that Mr. Lukashenko would be inaugurated as president for a new term within the next two months. The similarities in the election political dynamics of the two countries are reflective of manipulative, authoritarian regimes. The thought that two tyrannical regimes are attracted to each other because of their political vulturism mode of the ruling is a discussion open for debate among scholars.

The international relations actors voiced with condemnation the way the Zimbabwean 2018 and Belarus 2020 elections were conducted. S Meredith (2020) reported that E.U. High Representative for Foreign Affairs and Security Policy Josep Borrell on 14 August declared that the E.U. is going to bring in sanctions against Belarusian officials accountable for violence and misrepresentation. Charles Michel President of the European Council on 19 August, said the E.U. would soon enforce sanctions on a sizeable number of individuals answerable for violence, authoritarianism, and election racket. Lesley Wroughton reported that the Zimbabwe International Election Observation Mission (ZIEOM) had uttered doubts that the poll had a standard accepting value. Manisha Singh, the U.S. Assistant Secretary of State for Economic and Business Affairs, said that until the new government of President Emmerson Mnangagwa shows signs of changing its ways, the U.S.A government will not lift sanctions against Zimbabwe. However, it should be noted that there has not been a change between the Mugabe regimes to Mnangagwa regime regarding political reform. R Southhall (2017) argues that rather than sustaining "Mugabe without Mugabe-ism," Mnangagwa is enough of a radical and realist to diagnose that there is no way out of the present Zimbabwean crisis without some considerable political and economic reform. Against that background, he is a very unlikely democrat. Thus, he will seek to meet popular pressures from below by imposing authoritarian reform from above.

The two countries have a strained relationship with the U.S.A. The government of Belarus has been accused of suppressing anti-Lukashenka civil societies and Non-Governmental Organisations. Belarus government made it clear increasingly difficult for USA-based N.G.O.s to operate in Belarus. The Belarus government is under sanctions from the U.S.A. In 2004 the U.S.A. passed the Belarus Democracy Act, which authorised funding for anti-government Belarusian N.G.O.s and prohibited loans to the Belarusian government, except for humanitarian purposes. However, despite this friction, the two countries cooperate on intellectual property protection, prevention of human trafficking, technology crime, and disaster relief. Mugabe ruled Zimbabwe for 37 years and was labelled a tyranny by several democratic activists. Desmond Tutu of South Africa labelled Mugabe "a cartoon figure of an archetypal African dictator ".Melber H and Southall R (2017) wrote that critics had labelled the President Mnangagwa Government as an authoritarian regime and Zimbabwe's foreign policy implementation as disastrous to Zimbabwe's re-engagement efforts.) In Belarus, Alexander Lukashenko has served as the country's first president since 1994. Belarus has been labelled "Europe's last dictatorship" by some western journalists on account of Lukashenka's self-described authoritarian style of governance. The similarities in political behaviours indicate that the law of attraction is a universal law that can determine state relations.

\section{Conclusion}

The foreign relations between Zimbabwe and Belarus exhibit the power of the law of attraction in determining relations in the international system. However, the current political dynamic in the two counties will determine the future of the foreign relations between Zimbabwe and Belarus. In Zimbabwe, there are efforts to reengage with the West. The United Kingdom seems to have softened its stance on Zimbabwe, whilst in Belarus, the 2020 elections have ignited attention from the international community with the crackdown on protest. The post-2020 Belarus era and post-2020 political situation in Belarus will test the relations between Zimbabwe and Belarus. A change in government in either one of the two counties will likely lead to a change in philosophical thinking, international tolerance and acceptance, and a change or continuity in the national interests. This will mean the law of attraction will play a new role in determining the relations shortly, specifically whether or not the two counties will remain allies 


\section{References}

Acoulon S. G. (2020) Belarus Detains Journalist Who Exposed Corruption, OCCRP, Published: Monday, 30 March 2020 https://www.occrp.org/en/daily/11949-belarus-detains-journalist-whoexposed-corruption (Accessed 22 July 2020)

Blackstone K (2020), Primary, Secondary, Tertiary Sources, Research guide, University of Maryland Library, https://lib.guides.umd.edu/c.php?g=327327\&p=2195975 (Accessed 11/07/2020)

Bryman A (2011). Business research methods. Bell, Emma, 1968- (3rd Ed.). Cambridge: Oxford University Press. ISBN 9780199583409. OCLC 746155102. (Accessed 10/05/20)

Bwititi K (2015), Zimbabwe: V.P. Mnangagwa meets Belarusian President Zimbabwe: https://allafrica.com/stories/201507210285.html, (Accessed 21/07/21)

Chingono N (2019) Minister held over US\$95 Million Scandal, The Zimbabwe Independent, The Leading Business Weekly, posted 26 July, 2019, https://www.theindependent.co.zw/2019/07/26/minister-held-over-us95m-scandal// (Accessed 12 July 2020)

GlobalSecrity.Org,

Belarus-Foreign

Relations, https://www.globalsecurity.org/military/world/belarus/forrel.htm (Accessed 07/07/21)

GlobalSecurity.Org, Zimbabwe-Foreign Relations https://www.globalsecurity.org/military/world/africa/zw-forrel.htm (Accessed 07/07/21)

Griffiths M and Callaghan T. O (2002), International Relations, The Key Concepts, Routledge, Taylor and Francis, London and New York,

Heywood A (2007), Politics, 3rd Edition, Palgrave Macmillan, Hampshire, UK

Hove M, Ndawana E and Nhemachena M A (2020) How Cuba Survived Sanctions and Lessons for Zimbabwe, Jadavpur Journal of International relations, Vol, 24, 2, pp 192-195

Karombo T 2019, Zim Live.com, In Zanu P.F., corruption is no sin. So who's upset with Priscilla Mupfumira? https://www.zimlive.com/2019/07/26/in-zanu-pf-corruption-is-no-sin-so-whosupset-with-prisca-mupfumira/+\&cd=6\&hl=en\&ct=clnk\&gl=zw (Accessed 11/07/2020)

Lahviniec A and Papko (2010) Unfinished Business Challenges for Belarus on its way to Democracy, European View, Vol 9, 2 pp 253-262

March, J and Johan O. (1998), The Institutional Dynamics of International Political Orders, International Organization 52(4) 943-969.

Masunungure E and Badza S (2010) The internationalisation of the Zimbabwe Crisis, Multiple Actors, Competing Interest $t_{2}$ Journal of Development Societies, Sage Journals, Vol 26 Issues 2

Mavhunga C (2020) Zimbabwe Accused of Stifling Press Freedom as Journalist Denied Bail Again, https://www.voanews.com/africa/zimbabwe-accused-stifling-press-freedom-journalist-denied-bail-again (Accessed 9 August 2020)

Melder H and Southall R (2021), Zimbabwe's Foreign Policy under Mnangagwa, Vol 55, issue 2, pages 234-250, Journal of Asian and African Studies

Ministry of Foreign Affairs of the Republic of Belarus, Cooperation between the Republic of Belarus and Republic of Zimbabwe, http://rsa.mfa.gov.by/en/bilateral_relations/zimbabwe/ (Accessed 10/06/21)

Munyoro F, Zim, Belarus signs US\$350 deals, The Herald Zimbabwe, 18 September 2019, https://www.herald.co.zw/zim-belarus-sign-us350m-deals/

Onaf, N. G. (1989) as quoted in Stephen McMglinchey, Rosie Walters and Christian Scheinpflug (2007),_International Relations Theory, E- International Relations Publishing, Bristol, England, p36

Sasa M (2019), E.D. 's tour of Eurasia opens new Frontiers, The Herald Zimbabwe, and 23 January 2019

Sky News (Wednesday 19 August 2020) Belarus E.U. imposes sanctions as Lukashenko orders police to clear the streets, https://news.sky.com/story/eu-threatens-belarus-sanctions-as-it-rejectselection-result-12052472 (Accessed 02/05/21)

Southhall R (2017), Bob's Out, The Croc is in, Continuity or Change in Zimbabwe, Africa Spectrum, $\underline{52,3,81-94}$

The Embassy of the Republic of Belarus in the Republic of South Africa, Cooperation of the Republic of Belarus with the Republic of Zimbabwe, http://rsa.mfa.gov.by/docs/belarus_zimbabwe_en.pdf (Accessed 05/06/21) 
Tendi B.M (2014) The Origins and Functions of Demonisation Discourses in Britain-Zimbabwe Relations (2000-), Journal of Southern African Studies, 40:6, 1251-1269, DOI: $10.1080 / 03057070.2014 .933646$

Theyes.S (2017), Constructivism, edited by Stephen McMglinchey, Rosie Walters and Christian Scheinpflug (2007), International Relations Theory, E- International Relations Publishing, Bristol, England, p36

Trading Economics, Zimbabwe Corruption Index 1998-2019, https://tradingeconomics.com/zimbabwe/corruption-index (Accessed 05 August 2020)

Trantidis A (2021), Building an Authoritarian Region, Strategies for Autocratisation and Resistance in Belarus and Slovakia, British Journal of Politics and International Relations

Transparency International (2019) https://www.transparency.org/en/countries/belarus\# (Accessed 17 July 2020)

Van der Togt, T. (2017) Belarus, Russia, the EU and Integration of Integrations, Clingerndeal Institute, http://www.jstor.com/stable/resreo56463.5. (Accessed 01/06/21)

Wroughton L (2018) U.S. Sanctions to Remain until Zimbabwe Demonstrates Reforms, the Voice of America,

https://web.archive.org/web/20180917034216/https://www.voazimbabwe.com/a/zimbabweunited-nations-sanctions-in-place emmersonmnangagwa/4571385.html\#comments\#comments (Accessed 06/06/21)

Yaroshevic A (2018) NAVINY.BY, Why does President Executive Viktor Shreiman Fly to Zimbabwe 19/13/2018, https://naviny.by/article/20180913/1536836063-zachem-upravdelami-prezidentaviktor-sheyman-letaet-v-zimbabve (Accessed 10/05/20)

ZimNews (2020) Mnangagwa Shops for Military Technology Hardware in Belarus, https://zwnews.com/mnangagwa-shops-for-military-technology-hardware-in-belarus/ (Accessed 20/07/21)

Zimbabwe Market Watch News, Belarus offers 500 Buses to Zimbabwe, https://www.marketwatch.co.zw/belarus-offers-500-buses-to-zimbabwe/. (Accessed 10/06/21)

Zimbabwe's Statutory Instrument 79 of 2017 [CAP.18:24] Agriculture Marketing Authority (Command Agriculture Scheme for Domestic Crop, Livestock, and Fisheries Production) Regulations, 2017. 